\title{
Experimental Studies on Savonius Wind Turbine with Unidirectional Rotor House for High Speed Application
}

\author{
A Q Mohd Radzi ${ }^{1,3}$, M S Noorazizi ${ }^{2}$, N Mohd Ranai ${ }^{1,4}$ \\ ${ }^{1}$ Department of Mechanical, Polytechnic of Sultan Azlan Shah, Behrang Stesyen, 35950 Behrang, Perak, Malaysia, \\ 3 qoiyum@psas.edu.my, ${ }^{4}$ afzanranai@gmail.com \\ ${ }^{2}$ Razak Faculty of Technology and Informatics, Universiti Teknologi Malaysia, Jalan Sultan Yahya Petra, Kuala Lumpur, \\ Malaysia,noorazizi@utm.my
}

\begin{abstract}
Air Wheel Generator (AWG) is known as a vertical axis wind turbine with generator for renewable energy have been developed for low and high speed application. Recently, the various shapes of Savonius housing have been studied to improve its rotational speed and coefficient of rotor power. In this paper, Savonius wind turbine with unidirectional Rotor House (RH) for high speed application has been experimental studies to increase the revolution per minute (RPM) of the alternator and charging capability. The experiment on the AWG test stand was set up for different Blade Thickness (BT), $\mathrm{t}=0.9 \mathrm{~mm}, 1.2 \mathrm{~mm}, 1.5 \mathrm{~mm}$, and $2.0 \mathrm{~mm}$ where BT that has higher RPM will be the best rotor. The total of 4 test runs of passenger car installed with AWG was conducted using the best BT of the rotor. From the test run conducted on the highway road, the overall functionality of rotor and output voltage have been observed. The apparatus test stand requires verification with actual test run on passenger. On the other word, only the best BT with high RPM will be continued for further test stand for charging capability. Comparison of test stand and test run on passenger car show the blade with a thickness of $0.9 \mathrm{~mm}$ as the optimum blade thickness. AWG with Blade Guiders had the average speed rated of the alternator is $600 \mathrm{RPM}$ (V belt) and $400 \mathrm{RPM}$ (V Ribbed belt) as a switch is on for air speeds varies from 22.22 to $32.8 \mathrm{~m} / \mathrm{s}$. The standard Permanent Magnet Direct Current (PMDC) generator with the same average speed rate was proposed as good combinations for AWG with uni-directional RH. Hence, the conversion of car alternator as the standard permanent magnet that has water proof that may be used also with wind nozzle and lighter rotor material to increase the torque and power of the rotor in the future.
\end{abstract}

Key words : Air Wheel Generator, Savonius Wind Turbine, Rotor House, Passenger Car

\section{INTRODUCTION}

The term of air wheel generator has been used by researchers since the rotor and blades have appeared as a wheel physically and well-known called as wind turbine generators for electric generation. There are two types of wind turbine as Horizontal Axis Wind Turbine (HAWT), and Vertical Axis Wind
Turbine (VAWT) [1]. Amit et. al [2] performed experimentally on Savonius wind turbine with cylindrical cowling. By using cowling, the performance of the rotor has been improved by the wind flow improvement. Abdul Latif et. al [3] investigates the integration of Rotor House ( $\mathrm{RH})$ as wind accelerating. By using venture effect, the RH accelerates wind flow in the rotor zone to improve the power coefficient of rotor from 0.125 to 0.218 . Nabila et. al [4] using wind tunnel to investigate the effect of the upstream obstacle as wind deflector or guider on the Savonius wind turbine. By using the opening angle of obstacle have strongly to increase the rotor power and torque where the maximum performance at angle is 40 degrees. M. Mohammad et. al [5] investigated the flow augmentation and momentum exchange optimization on the Savonius wind turbine. By installing a simple nozzle with tail in front of rotor with double-curved two stage bucket as rotor displayed the best performance. All these paper performed the wind gathering and booster device for low speed application for a tower and static structure.

However, Unidirectional Rotor House (RH) for high speed Savonius wind turbine application on passenger car still has shown lack of studies. It requires of apparatus set up for optimization of various Blade Thickness (BT), the vertical load effect on rotational of alternator in RPM, and to evaluate the function of components for high speed of wind. This paper presents experimental studies on Savonius wind turbine with unidirectional Rotor House (RH) for high speed application. The test stand with apparatus set up have been performed for increasing the rotational speed of the alternator and charging capability. The test stand apparatus requires functionality verification on passenger car before further improvement on AWG components for the best experiment results. The minimum average rated speed for charging requirement for alternator used were verified with comparative study according to other researchers.

\section{EXPERIMENTAL}

\subsection{Design of Experiments}

The schematic of experimental stand as shown in Figure 1. The standard design of the experiment is referred to According to ISO 8854 and SAE J 56 [6], the standard of 
procedure for charging performance for road vehicle alternator. The relevant parameter such as voltage, current, and RPM reading were measured according to the standard of procedure for charging performance for road vehicle alternator, SAE J 56 [6]. Therefore, Table 1 listed the apparatus set up for experimental test stand on AWG. All devices were prepared with relevant technical and standard of procedure to assure the correct data collection.

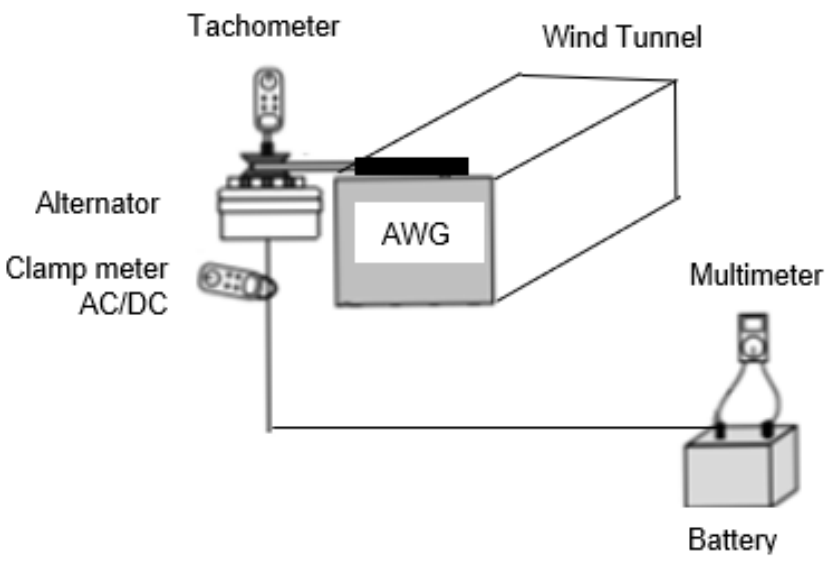

Figure 1: Schematic Diagram of Experimental Test Stand on the AWG

Table 1: Apparatus Set Up List in Test Stand on the AWG

\begin{tabular}{|c|c|c|c|}
\hline No. & Devices & Features & Function \\
\hline 1 & Wind tunnel & $\begin{array}{l}\text { - Aluminum Plastic } \\
\text { Composite } \\
-0.3 \mathrm{~m} \times 0.3 \mathrm{~m} \times 1.22 \mathrm{~m}\end{array}$ & $\begin{array}{l}\text { Air flow with } 4 \text { speed } \\
22.2 \mathrm{~m} / \mathrm{s}, 26 \mathrm{~m} / \mathrm{s}, 29.5 \\
\mathrm{~m} / \mathrm{s} \text {, and } 32.8 \mathrm{~m} / \mathrm{s}\end{array}$ \\
\hline 2 & Air Blower & $\begin{array}{l}\text { Brand: Bosch } \\
\text { Model: GBL } 82270 \\
\text { Max. wind speed: } 4.5 \\
\mathrm{~m}^{3} / \mathrm{min}\end{array}$ & $\begin{array}{l}\text { To supply air source } \\
\text { with speed adjustment }\end{array}$ \\
\hline 3 & Battery & $\begin{array}{l}\text { Car battery } 12 \mathrm{~V} \\
\text { Brand: Century } \\
\text { Marathoner NS60LS }\end{array}$ & $\begin{array}{l}\text { To store the charging } \\
\text { current }\end{array}$ \\
\hline 4 & Alternator & $\begin{array}{l}\text {-Reconstructed type } \\
\text {-Brand: Powertron }\end{array}$ & $\begin{array}{l}\text { To generate charging } \\
\text { current }\end{array}$ \\
\hline 5 & AWG & $\begin{array}{l}-1 \text { Unidirectional Rotor } \\
\text { House } \\
-1 \text { Rotor Hub } \\
-4 \text { blades with thickness, t= } \\
0.9 \mathrm{~mm}, 1.2 \mathrm{~mm}, 1.5 \mathrm{~mm}, \& \\
2.0 \mathrm{~mm}\end{array}$ & $\begin{array}{l}\text { To convert } \\
\text { aerodynamic loads to } \\
\text { shaft rotation. }\end{array}$ \\
\hline 6 & $\begin{array}{l}\text { Belting } \\
\text { System }\end{array}$ & $\begin{array}{l}\text {-V belt } \\
\text {-PK V Ribbed belt }\end{array}$ & $\begin{array}{l}\text { To multiply torque } \\
\text { and rotation RPM }\end{array}$ \\
\hline 7 & Iron Stand & $\begin{array}{l}\text { Modified from existing } \\
\text { stand for vice mounting in } \\
\text { the lab }\end{array}$ & $\begin{array}{l}\text { To hold AWG at the } \\
\text { height of } 95 \mathrm{~cm}\end{array}$ \\
\hline 8 & $\begin{array}{l}\text { Digital } \\
\text { Multimeter }\end{array}$ & Brand: Fluke & $\begin{array}{l}\text { To read alternator } \\
\text { voltage DC }\end{array}$ \\
\hline 9 & Anemometer & $\begin{array}{l}\text { Brand: Lutron model } \\
\text { AM4202 }\end{array}$ & $\begin{array}{l}\text { To read wind speed } \\
\text { and temperature up to } \\
30 \mathrm{~m} / \mathrm{s}\end{array}$ \\
\hline 10 & Tachometer & $\begin{array}{l}\text { Brand: Lutron model } \\
\text { DT-2230 }\end{array}$ & Measure RPM \\
\hline 11 & $\begin{array}{l}\mathrm{AC} / \mathrm{DC} \\
\text { clamp meter }\end{array}$ & $\begin{array}{l}\text { Brand: Uni-T model } \\
\text { UT203 }\end{array}$ & Measuring DC current \\
\hline
\end{tabular}

\subsubsection{Wind Tunnel}

Figure 2a shows wind tunnel built from 4 sheets of aluminum plastic composite (APC) panel with $0.3 \mathrm{~m}$ height, $0.3 \mathrm{~m}$ width and $1.22 \mathrm{~m}$ length that were jointed using 12 pieces of elbow joint that installed at 3 locations; inlet, middle, and outlet. The masking tape was used to close the gap at the 4 angles so that there is no air leaking when running the air blower as shown in Figure $2 b$.

The use of leaf blower [7], fan blower [8] as a pressure source in rotating the blade were performed experimentally during the test stand on Wind Turbine to measure the RPM before applying it to a passenger car. Therefore, the air blower brand Bosch model GBL 82270 with outlet wind speed 4.5 $\mathrm{m}^{3} /$ min was used as wind speed sources in a wind tunnel as shown in Figure 2c. The researcher mentioned the wind speed as the similar to the vehicle speed, $v$ in $\mathrm{m} / \mathrm{s}$.

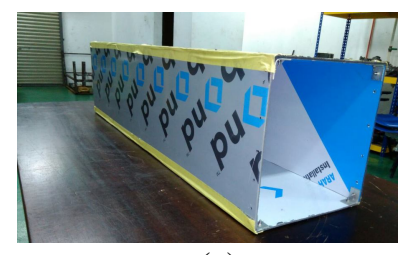

(a)

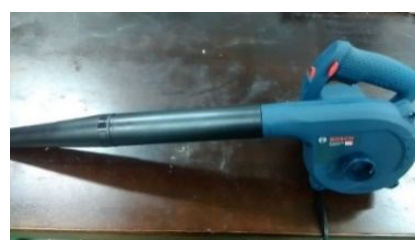

(b)

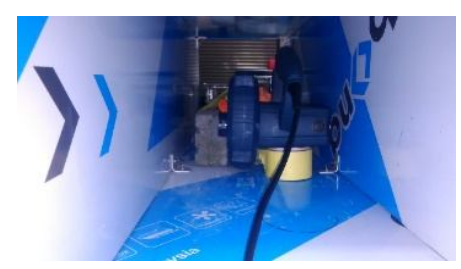

(c)

Figure 2: a) Wind Tunnel B) Air Blower C) Stone Wrapped on the Air Blower in the Wind Tunnel

\subsubsection{Instrumentation}

The anemometer has been used in determining the position of the air blower nozzle outlet to the center of AWG shaft, L to set the different wind speed as shown in Figure 3. Table 2 depicted the 4 position of the air blower nozzle outlet to the shaft center and wind speed set up. The maximum speed of the blower was used in this set up for all positions where the blower nozzle and entrance center were set on the same level.

Table 2: Distance from Nozzle Outlet to the Center of Turbine Shaft

\begin{tabular}{|c|c|}
\hline Distance, $\mathbf{L}(\mathbf{c m})$ & Wind speed, $\mathbf{v}(\mathbf{m} / \mathbf{s})$ \\
\hline 61 & 22.22 \\
\hline 50 & 26 \\
\hline 43 & 29 \\
\hline 36 & 32.8 \\
\hline
\end{tabular}




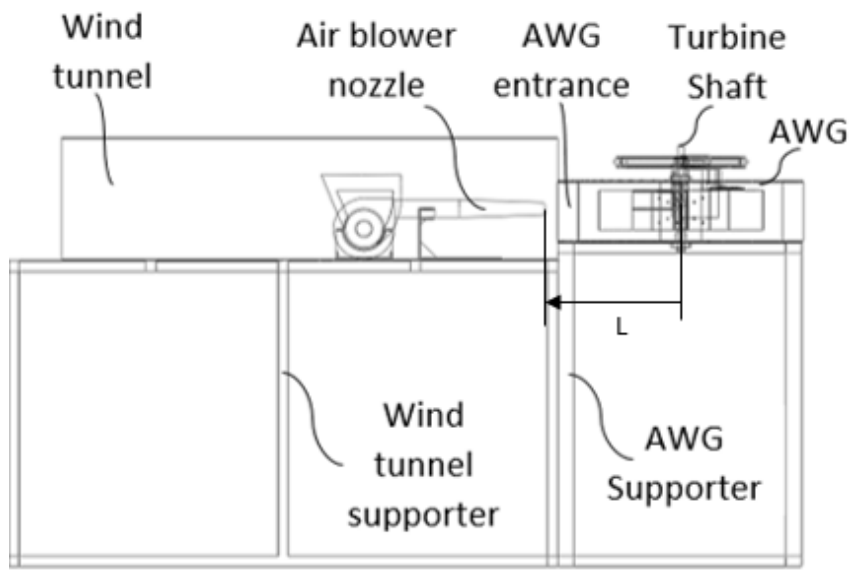

Figure 3: Air Blower Levelling and the Position Set Up

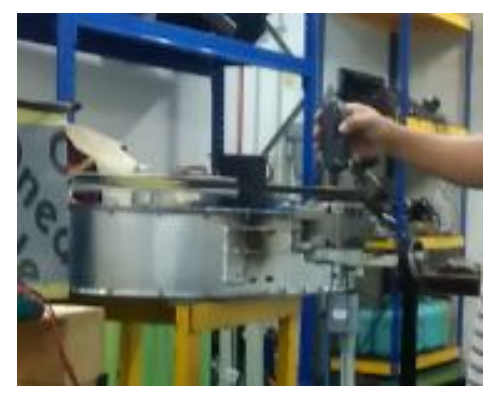

Figure 4: RPM measurement using tachometer

The tachometer was used in measuring the RPM as shown in Figure 4a. There are two modes of rotational data using tachometer were used in the test stand are; mode 1-direct contact (readings in RPM) and mode 2 surface contact (readings in $\mathrm{m} / \mathrm{min}$ ) which both of them were applied to alternator shaft, and the main pulley on the upper surface of rim respectively. Hence, only 2 modes are used as mentioned and can be verified easily from the direct readings and further conversion for $\mathrm{m} / \mathrm{min}$ to RPM value for analytical calculation based on experimental data.

\subsubsection{Wiring of Alternator Unit}

The wiring diagram of alternator as the basis in alternator wiring for overall charging system on actual car, Toyota. It requires the understanding the operation of the alternator and relevant component. The two types of wiring condition are; regulator supplied and not supplied. Therefore, in the experimental set up, the setting of wiring was mentioned for each test stand's experimental sheets data collection.

The setting of experimental allows the data can be evaluated and compare with others set up data for further discussion in Section 3.0. The term of "switch on" will be used to supply the current from the battery to the regulator, thus activating magnetic effect on the alternator. Conversely, the "switch off" will be used for no magnetic effect on the same alternator coil.
There are three types of wires out from the alternator regulator connector; L, IG and S as depicted in Table 3. The correct wiring is very significant for the functionality of each wire where the ignition switch is referring to the switch on/off, instead of the ignition switch for the engine using the key of the car at the driver side.

Table 3: Three wires of alternator connector

\begin{tabular}{|c|c|c|c|}
\hline $\begin{array}{c}\text { Wire } \\
\text { Nable }\end{array}$ & Wire & Definition & Function \\
\hline 1 & L & $\begin{array}{c}\text { Alternator Charge } \\
\text { Warning Light }\end{array}$ & $\begin{array}{c}\text { Turn the alternator } \\
\text { charge warning light } \\
\text { ON / OFF }\end{array}$ \\
\hline 2 & IG & Ignition Switch & $\begin{array}{c}\text { Determine if the ignition } \\
\text { is ON. }\end{array}$ \\
\hline 3 & S & Battery Voltage Sense & $\begin{array}{c}\text { Sense the voltage at the } \\
\text { battery }\end{array}$ \\
\hline
\end{tabular}

Figure 5a is the photo of complete wiring set up in the test stand using Reconstructed Myvi alternator model Powertron. The on/off switch in Figure 5b can be used instead of using the ignition switch that functions to crank the engine in a passenger car. The warning lamp is used as charging indicator in the test stand where the air blower as wind loads in rotating the wind turbine blade.

For charging capability, it requires sufficient rotational of the alternator shaft, $\mathrm{N}$ at more than $2000 \mathrm{RPM}$ [9], $1200 \mathrm{RPM}$ [10], 1070 RPM [11] and 1400 RPM [12] to cause the lamp is off (when the switch is on), which notified the charging voltage is higher than battery voltage is ongoing from alternator to battery as shown in Figure 5c. Conversely, if the lamp in Figure 5d is on (when the switch is on), it indicating that no electrical power produce from the alternator to the battery via the indicator lamp when insufficient alternator speed below than their minimum speed.

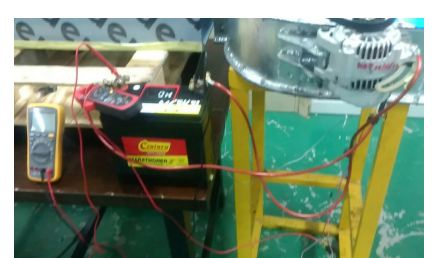

(a)

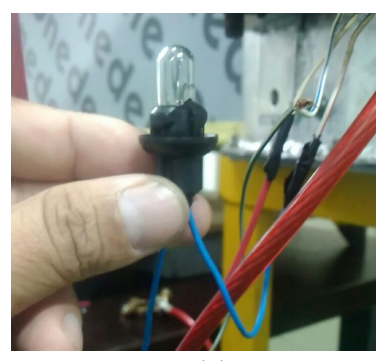

(c)

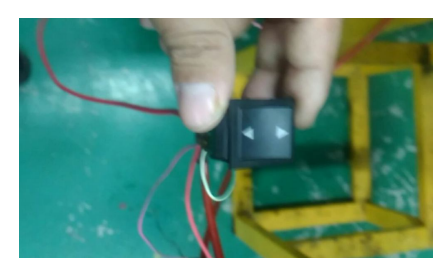

(b

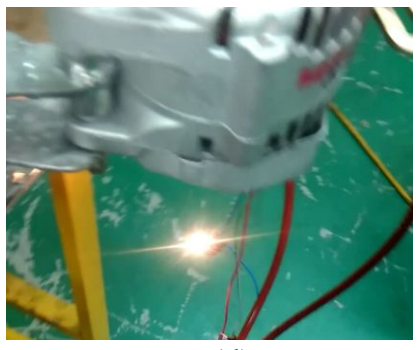

(d)
Figure 5: a) Completed Wiring on the AWG using Reconstructed Myvi Alternator b) On/Off Switch c) Warning Lamp is Off

d) A Warning Lamp is On 


\subsubsection{Air Wheel Generator on Stand}

AWG with the unidirectional RH as shown in Figure 6 at three perspective view. The test stand requires the AWG to have the stability as car moving from $80 \mathrm{~km} / \mathrm{h}$ to $118 \mathrm{~km} / \mathrm{h}$ and the height of $95 \mathrm{~cm}$ may be simplified as AWG on the top roof of the passenger car where the flow direction of air blower via wind tunnel is opposite from vehicle direction. Due to safety of Test stand on AWG, the arrangement and functionality of each component were checked before the data collection will be done for test stand.

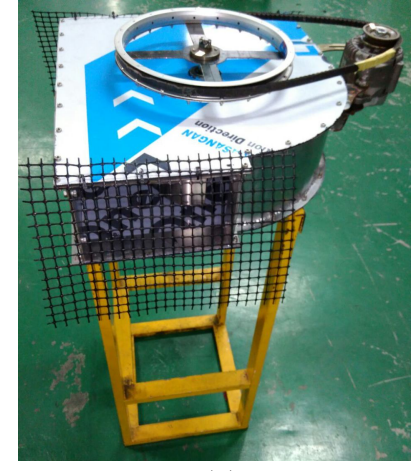

(a)

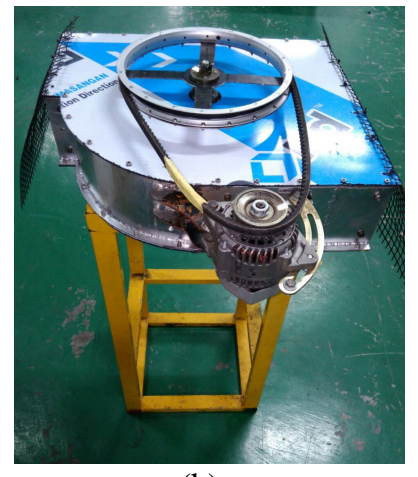

(b)

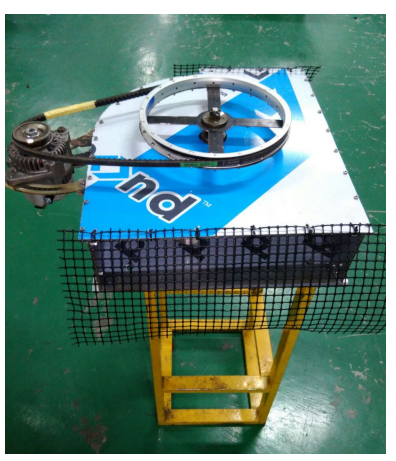

(c)

Figure 6: Perspective view of AWG a) Front b) Side c) Back

\subsection{Experimental Test stand on AWG}

Three types of test stand set up were done according to the 3 types of experimental set up as follow:

Firstly, the test stand for optimization the best of BT, $t=0.9$ $\mathrm{mm}, 1.2 \mathrm{~mm}, 1.5 \mathrm{~mm}, \& 2.0 \mathrm{~mm}$ at speed, $v=22.22 \mathrm{~m} / \mathrm{s}$ where V Ribbed belt was used for a minimum of 4 tests for each BT. Secondly, the test stand using BT $t=0.9 \mathrm{~mm}$ for V Belt to determine best BT wind speeds, $v=22.22 \mathrm{~m} / \mathrm{s}$ till $32.8 \mathrm{~m} / \mathrm{s}$ without BG and followed by the test run of passenger car for verifying data and blade functionality. Thirdly, the test stand for BT, $t=0.9 \mathrm{~mm}$ for determining the RPM and charging capability using BT $t=0.9 \mathrm{~mm}$ for V Belt and V Ribbed Belt from wind speeds, $v=22.22 \mathrm{~m} / \mathrm{s}$ till $32.8 \mathrm{~m} / \mathrm{s}$ with BG.

\subsection{Test Run AWG on Passenger Car}

The standard roof mounting and bracket were used to mount the AWG on the top roof of the Toyota Avanza 1.3 Manual as shown in Figure 7a. The instrumentation wire via the door as shown in Figure 7b, where the only 2 wires with length of 3 meters each one which are connected to multimeter inside the car. The test run was done 4 times along the Guthrie Corridor Express Highway from Bukit Subang to Bukit Beruntung, Selangor where the reading of multimeter and vehicle speed were monitored and recorded using mounted camera. The finding will be described in Section 3.0.

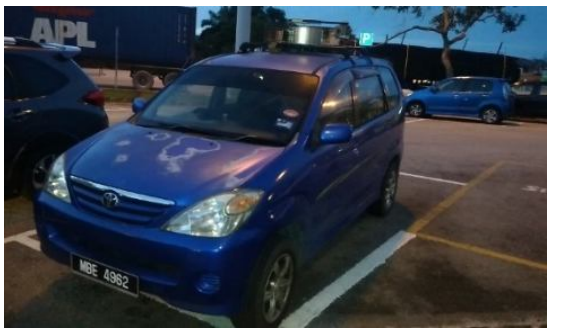

(a)

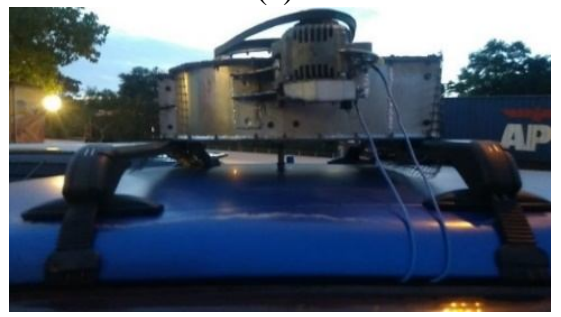

(b)

Figure 7: a) Toyota Avanza 1.3 Manual b) AWG mounted on the top roof

\section{EXPERIMENTAL RESULTS}

\subsection{Test Stand using Belt: $4 \mathrm{PK} V$ Ribbed $(\mathrm{t}=9 \mathrm{~mm}$ to 2.0mm; without BG)}

Referring to Table 4, the researcher found the longest time of running time on each BT were causing the higher output voltage for duration test about 5 minutes for each one (Test 1 till Test 4) where no any electrical supply to the regulator. From this results, without the BG or holder, the blade area was expanded by wind loads, thus increasing the drag force. Despite of that, the blade $\mathrm{t}=0.9 \mathrm{~mm}$ shows the higher output voltage about $103 \mathrm{mV}$ for duration test about 25 minutes (Test $5)$.

Table 4: Maximum Output Voltage test run of AWG (Belt: 4PK V Ribbed; $t=9 \mathrm{~mm}$ to $2.0 \mathrm{~mm}$; without BG).

\begin{tabular}{|c|c|c|c|c|c|}
\hline \multirow{2}{*}{ BT } & \multicolumn{5}{|c|}{ Alternator Voltage Output (mV) } \\
\cline { 2 - 6 } & Test 1 & Test 2 & Test 3 & Test 4 & Test 5 \\
\hline $\mathrm{t}=0.9 \mathrm{~mm}$ & 43.2 & 61.6 & 75.1 & 81 & 103 \\
\hline $\mathrm{t}=1.2 \mathrm{~mm}$ & 15.5 & 14.6 & 18.4 & 20 & 25.1 \\
\hline $\mathrm{t}=1.5 \mathrm{~mm}$ & 9.3 & 9.8 & 8.2 & 7.8 & - \\
\hline $\mathrm{t}=2.0 \mathrm{~mm}$ & 4.8 & 6.4 & 7.3 & 8.3 & - \\
\hline
\end{tabular}

Note: Test 5 only for BT, $t=0.9 \mathrm{~mm}$ and $t=1.2 \mathrm{~mm}$ 
The average voltage output using of blade with a thickness, $t=$ $0.9 \mathrm{~mm}$ about $88 \mathrm{mV}$ with highest wheel turbine speed, $N=181.2$ RPM and alternator speed, $N=920$ RPM as compared to AWG with BT, $t=1.2 \mathrm{~mm}$. Thus, proved that the lower mass of blade is better for higher rotational speed, $N$ in RPM values. The optimum BT as preferred, $t=0.9 \mathrm{~mm}$ is the closest option according to numerical analysis results that suggested the BT, $t=1.0 \mathrm{~mm}$ of stainless steel 304 has sufficient in term of strength due to wind loads [13].

\subsection{Test Stand using Belt: V Belt $(t=9 \mathrm{~mm}$ without BG)}

According to Table 5, the RPM of the turbine and alternator increased slightly from $v=22.2 \mathrm{~m} / \mathrm{s}$ till $v=32.8 \mathrm{~m} / \mathrm{s}$ with ratio is in the range 4.15 to 4.24 that proved the effectiveness of belting system in multiply as $\mathrm{G}=4.32$ of revolution to the alternator shaft.

Table 5: RPM of Turbine and Alternator in 5 minutes test run of AWG

(Belt: V Belt; $t=0.9 \mathrm{~mm}$; without BG)

\begin{tabular}{|l|c|c|c|c|}
\hline \multirow{2}{*}{$\begin{array}{l}\text { Pulley } \\
\text { Readings }\end{array}$} & \multicolumn{4}{|c|}{ RPM } \\
\cline { 2 - 5 } & $\mathbf{v = 2 2 . 2 m} / \mathbf{s}$ & $\mathbf{v = 2 6 m} / \mathbf{s}$ & $\mathbf{v}=\mathbf{2 9 . 5 m} / \mathbf{s}$ & $\mathbf{v = 3 2 . 8 m} / \mathbf{s}$ \\
\hline Turbine & 223.6 & 276.4 & 296.8 & 340.9 \\
\hline Alternator & 929 & 1140 & 1238 & 1444 \\
\hline Ratio & 4.15 & 4.12 & 4.17 & 4.24 \\
\hline
\end{tabular}

Figure 8 shows the rotation of rotor turbine; $\mathrm{N}$ directly depends on the increased wind speed. With the high torque capability of 4 blades as proved by [14] resulting the high RPM for AWG which is easily can be achieved in one minute by wind speed using air blower. Thus, the good relationship between alternator and rotor RPM and wind speed as the best indicator the potential of AWG application using uni-directional RH on passenger car.

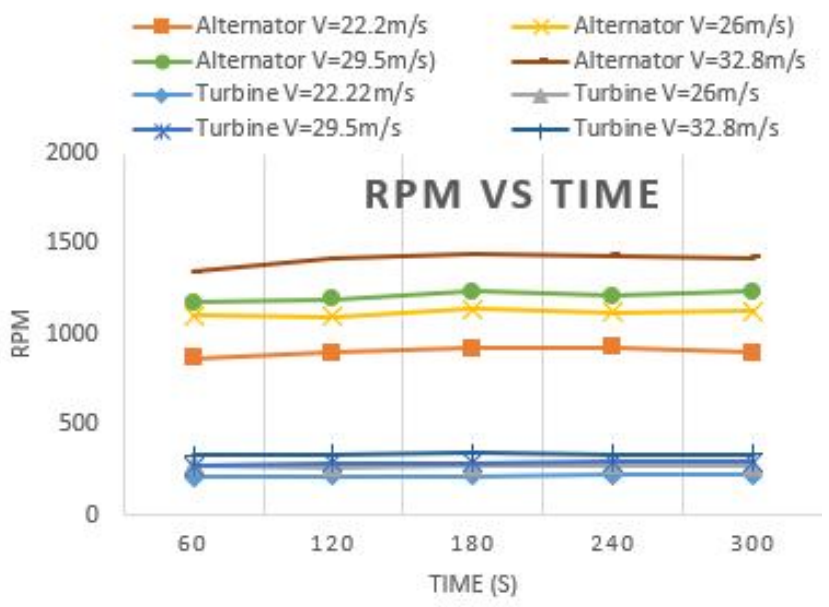

Figure 8: RPM of Turbine and Alternator in 5 minutes test run of AWG (Belt: V Belt; $t=0.9 \mathrm{~mm}$; without BG)

\subsection{Test Run on Passenger Car (Belt: V Belt; $t=0.9 \mathrm{~mm}$; without BG)}

From the test run of the AWG on Toyota Avanza 1.3 manual, the minimum rotational of blade start at $80 \mathrm{~km} / \mathrm{h}$ and slightly increase as the speed is increased till $110 \mathrm{~km} / \mathrm{h}$. The test run on passenger were done successfully in the Guthrie Corridor Expressway Highway in the morning on 4 December 2019 between 6.15 am to 7.30 am (the road is empty condition and less number of cars).

As the vehicle speed varies from $80 \mathrm{~km} / \mathrm{h}$ to $110 \mathrm{~km} / \mathrm{h}$, then it resulting the maximum output voltage reach up to more than $118 \mathrm{mV}$ as shown in Test 1 and Test 2 which has value of $125.5 \mathrm{mV}$ and $122.2 \mathrm{mV}$ respectively as shown in Figure 9a. While, for Test 3 and Test 4 have value of maximum output voltage up to $148.5 \mathrm{mV}$ and $147.5 \mathrm{mV}$ respectively. Both Test 3 and Test 4 have been stopped as car was slow down as there has the collision between the blades and $\mathrm{RH}$ occurred when vehicle speed reach at $30.5 \mathrm{~m} / \mathrm{s}$ as shown in Figure $9 \mathrm{~b}$. As a result, in the next Section 3.4, the AWG with the BG were tested to improve the stability when rotation at the higher RPM to solve this collision.

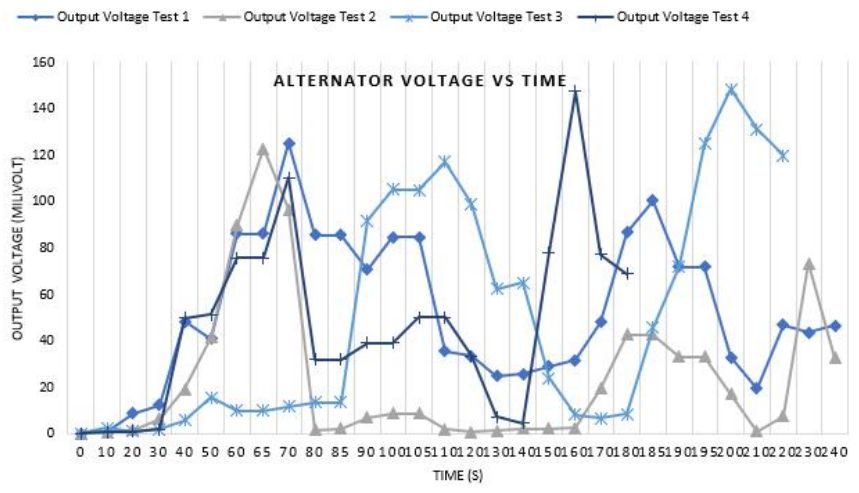

(a)

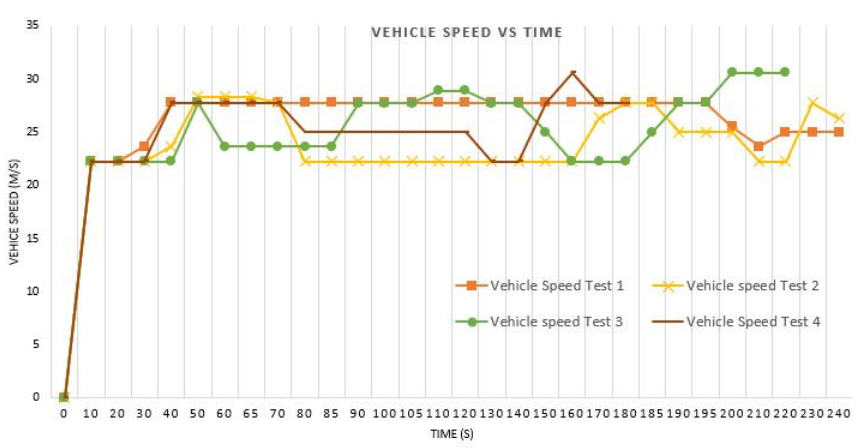

(b)

Figure 9: Test Run of AWG on Passenger Car a) Output Voltage versus Time for 4 Tests. b) Vehicle Speed versus Time for 4 Test. 


\subsection{Test Stand using V Belt with BG}

The test stands on AWG using V Belt with BG on BT $t=9 \mathrm{~mm}$ was solved the collision between the blade and the Rotor House. The steel bracket with hole $5 \mathrm{~mm}$ were used as a BG as shown in Figure 10a and Figure 10b which mounted at lower and upper location respectively. Blade $1 \& 2$ (opposed position) has lower mounted BG, while blade $3 \& 4$ (opposed position) has upper mounted BG where blade numbering can be referred to Figure 10c.

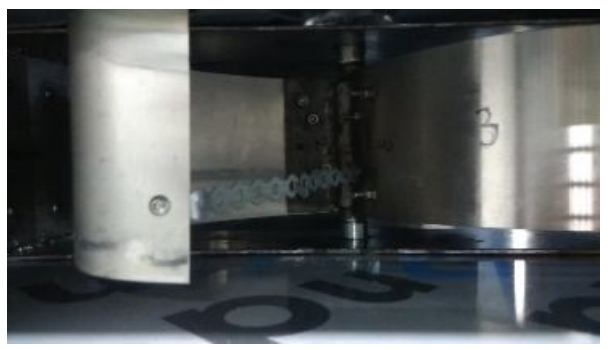

(a)

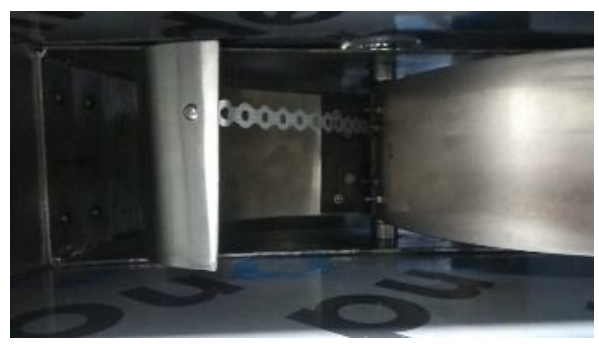

(b)

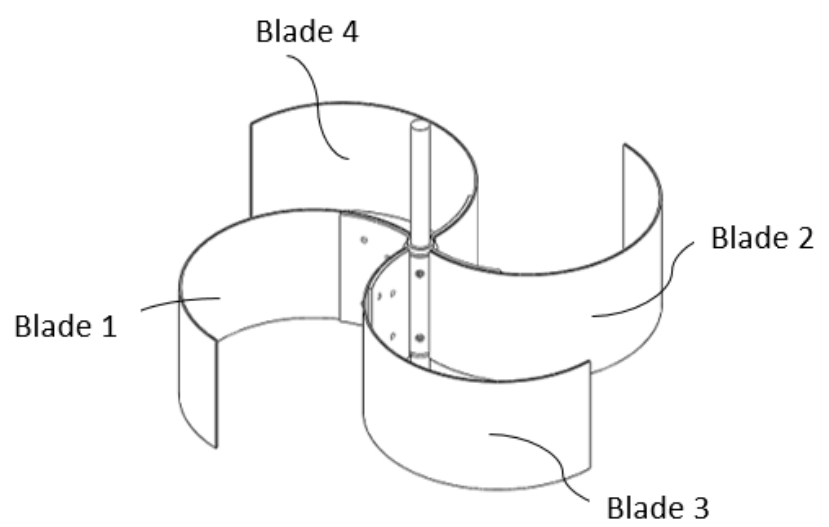

(c)

Figure 10: $\mathrm{BG}$ uses $5 \mathrm{~mm}$ bracket for 4 blades with up and down location of $\mathrm{BG}$.

a) Blade $1 \& 2$ b) Blade $3 \& 4$ c) Rotor drawing

Table 6 depicted the average voltage generated in 5 minutes test run of AWG with $\mathrm{V}$ belt, BT, $\mathrm{t}=9 \mathrm{~mm}$ with $\mathrm{BG}$ before the switch is on. Table 6 also shows the during switch is off, the wheel or turbine speed in the range of 248.58 to 334.23 RPM and the alternator speed varies in the range of 1073 to 1444.17 RPM for wind speed, v varies from $22.22 \mathrm{~m} / \mathrm{s}$ to 32.8 $(80 \mathrm{~km} / \mathrm{s}$ to $118 \mathrm{~km} / \mathrm{h})$. The speed ratio between alternator and wheel turbine have the values of 4.26 to 4.34 equal to value of $\mathrm{G}=4.3$ for $\mathrm{V}$ Belt. Hence, its proven the belting system increased the rotational speed, $\mathrm{N}$ for alternator RPM.

Conversely, as the switch is on, the alternator speed, $\mathrm{N}$ varies in the range of 487 to 758 RPM with average about 670 RPM (alternator speed rate $600 \mathrm{RPM}$ ), while the turbine rotation varies in the range of 109.2 to $180.3 \mathrm{RPM}$ with average about 157.85 RPM for wind speed from $22.22 \mathrm{~m} / \mathrm{s}$ to $32.8(80 \mathrm{~km} / \mathrm{s}$ to $118 \mathrm{~km} / \mathrm{h}$ ). The alternator speed, $\mathrm{N}$ losses for all wind speed of $\mathrm{v}=22.22 \mathrm{~m} / \mathrm{s}$ to $32.8 \mathrm{~m} / \mathrm{s}$ are $45.86 \%$ to $47.8 \%$ for turbine, while $47.5 \%$ to $48.7 \%$ for alternator as the switch is on.

The energized rotor coil which has the electromagnetic field were slow down the alternator speed. As refer to Figure 11, only test stand with wind speed, $\mathrm{v}=22.22 \mathrm{~m} / \mathrm{s}$ shows the RPM below than 1400 RPM [12], thus no any current generated by alternator that caused the lamp is on along the test period. Conversely, for $\mathrm{v}=26 \mathrm{~m} / \mathrm{s}, 29 \mathrm{~m} / \mathrm{s}$, and $32.8 \mathrm{~m} / \mathrm{s}$ have current generated are $3.57 \mathrm{~A}, 3.23 \mathrm{~A}$, and $3.17 \mathrm{~A}$ respectively [12] as lamp also off about $2 \mathrm{~s}$ before the lamp is on again due to reduction of alternator speed below 1400 RPM.

Table 6: Average RPM of Turbine and Alternator in 5 minutes test run of AWG for different wind speed (V Belt; $\mathrm{t}=0.9 \mathrm{~mm}$; with $\mathrm{BG}$ )

\begin{tabular}{|l|c|c|c|c|}
\hline \multirow{2}{*}{$\begin{array}{l}\text { Pulley } \\
\text { Readings }\end{array}$} & \multicolumn{4}{|c|}{ RPM (Switch is Off) } \\
\cline { 2 - 5 } & $\mathbf{v = 2 2 . 2 m / \mathbf { s }}$ & $\mathbf{v = 2 6 m} / \mathbf{s}$ & $\mathbf{v = 2 9 . 5 m / s}$ & $\mathbf{v = 3 2 . 8 m / \mathbf { s }}$ \\
\hline Turbine & 248.58 & 333.05 & 314.08 & 334.23 \\
\hline Alternator & 1073 & 1444.17 & 1345.5 & 1423.17 \\
\hline Ratio & 4.32 & 4.34 & 4.28 & 4.26 \\
\hline & \multicolumn{5}{|c|}{ RPM (Switch is On) } \\
\hline Turbine & 109.2 & 180.3 & 167.5 & 174.4 \\
\hline Alternator & 487 & 758.3 & 706.8 & 730 \\
\hline Ratio & 4.46 & 4.2 & 4.22 & 4.19 \\
\hline & \multicolumn{5}{|c|}{ \% RPM Losses } \\
\hline Turbine & 56.1 & 45.86 & 46.67 & 47.8 \\
\hline Alternator & 54.61 & 47.5 & 47.47 & 48.7 \\
\hline
\end{tabular}

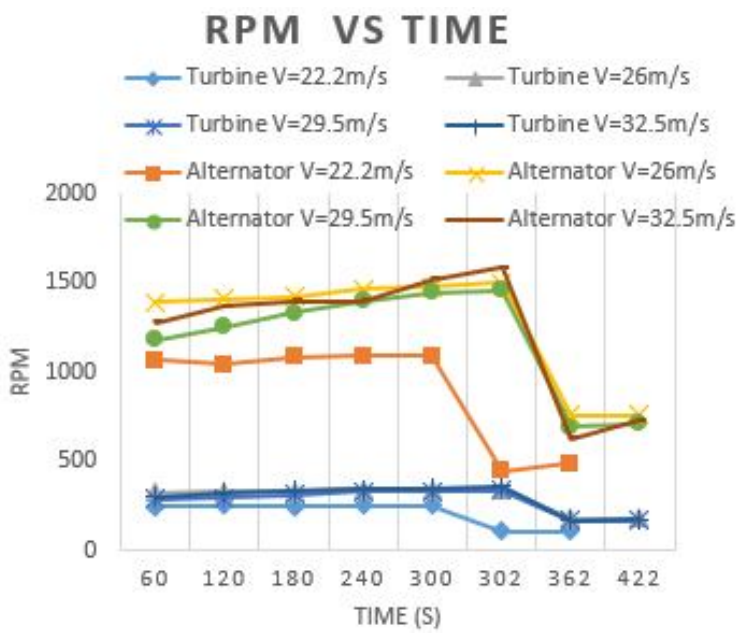

Figure 11: RPM of Turbine and Alternator in 5 minutes test run of AWG (Belt: V Belt; $\mathrm{t}=0.9 \mathrm{~mm}$; with BG) 


\subsection{Test Stand using V Ribbed Belt with BG}

Table 7 depicted the average voltage generated in 5 minutes test run of AWG with V Ribbed belt, BT, $t=9 \mathrm{~mm}$ with BG before the switch is on. During switch is off, the wheel or turbine speed in the range of 193.38 to 339.46 RPM and the alternator speed varies in the range of 1051.6 to $1870.17 \mathrm{RPM}$ for wind speed, v varies from $22.22 \mathrm{~m} / \mathrm{s}$ to $32.8(80 \mathrm{~km} / \mathrm{s}$ to $118 \mathrm{~km} / \mathrm{h}$ ). The speed ratio between alternator and wheel turbine has the values of 5.4 to 5.66, with average of 5.5 that proved the belting system in increasing the rotational speed, $\mathrm{N}$ for Ribbed Belt.

Conversely, as the switch is on, the alternator speed, $\mathrm{N}$ varies in the range of 218.6 to 634 RPM with average about 457.4 RPM (alternator speed rate 400 RPM), while the turbine rotation varies in the range of 40.16 to $113.2 \mathrm{RPM}$ with average about $84.84 \mathrm{RPM}$ for wind speed from $22.22 \mathrm{~m} / \mathrm{s}$ to $32.8(80 \mathrm{~km} / \mathrm{s}$ to $118 \mathrm{~km} / \mathrm{h})$. The alternator speed, $\mathrm{N}$ losses for wind speed of $\mathrm{v}=22.22 \mathrm{~m} / \mathrm{s}$ to $32.8 \mathrm{~m} / \mathrm{s}$ are $65.35 \%$ to 79.23 $\%$ for wheel turbine and $65.35 \%$ to $79.21 \%$ for alternator as the switch is on.

Table 7: Average RPM of turbine and alternator in 5 minutes test run of AWG for different wind speed

(V Ribbed Belt; $\mathrm{t}=0.9 \mathrm{~mm}$; with BG)

\begin{tabular}{|l|c|c|c|c|}
\hline \multirow{2}{*}{$\begin{array}{l}\text { Pulley } \\
\text { Readings }\end{array}$} & \multicolumn{5}{|c|}{ RPM (Switch is Off) } \\
\cline { 2 - 5 } & $\mathbf{v = 2 2 . 2 m} / \mathbf{s}$ & $\mathbf{v = 2 6 m} / \mathbf{s}$ & $\mathbf{v = 2 9 . 5 m} / \mathbf{s}$ & $\mathbf{v = 3 2 . 8 m} / \mathbf{s}$ \\
\hline Turbine & 193.38 & 314.17 & 323 & 339.46 \\
\hline Alternator & 1051.6 & 1698.33 & 1829.83 & 1870.17 \\
\hline Ratio & 5.43 & 5.4 & 5.66 & 5.5 \\
\hline & \multicolumn{5}{|c|}{ RPM (Switch is On) } \\
\hline Turbine & 40.16 & 91 & 113.2 & 95 \\
\hline Alternator & 218.6 & 470 & 634 & 507 \\
\hline Ratio & 5.44 & 5.16 & 5.6 & 5.33 \\
\hline & 79.23 & 71.03 & 65.35 & 72.01 \\
\hline Turbine & 79.21 & 72.32 & 65.35 & 72.89 \\
\hline Alternator & \multicolumn{5}{|c|}{ \%PM Losses } \\
\hline
\end{tabular}

The V Ribbed Belt has higher losses since it has a small diameter of the alternator pulley of $0.05 \mathrm{~m}$. Balta et. al performed slip measurement on V Ribbed Belt for the drive system and summarized that the smaller a pulley size, the larger for the belt slip, it is a nature of this belt [15]. During the experiment, there are poor fits between belt grove and pulley grooves. Increasing the braking torque causes a significant increase in slip for V Ribbed Belt alternator which has a lower speed rate approximately about 400 RPM as compared to V Belt which has 600 RPM.

In details, the energized rotor coil which has the electromagnetic field were slow down the alternator speed. As refer to Figure 12, only test stand with wind speed, $v=22.22$ $\mathrm{m} / \mathrm{s}$ shows the RPM below than 1400 RPM [12], thus no any current generated by alternator that caused the lamp is on along the test period. Conversely, for $\mathrm{v}=26 \mathrm{~m} / \mathrm{s}, 29 \mathrm{~m} / \mathrm{s}$, and $32.8 \mathrm{~m} / \mathrm{s}$ have current generated are $2.48 \mathrm{~A}, 2.52 \mathrm{~A}$, and 2.21 A respectively [12] as lamp also off about $2 \mathrm{~s}$ before the lamp is on again due to reduction of alternator speed below 1400 RPM.

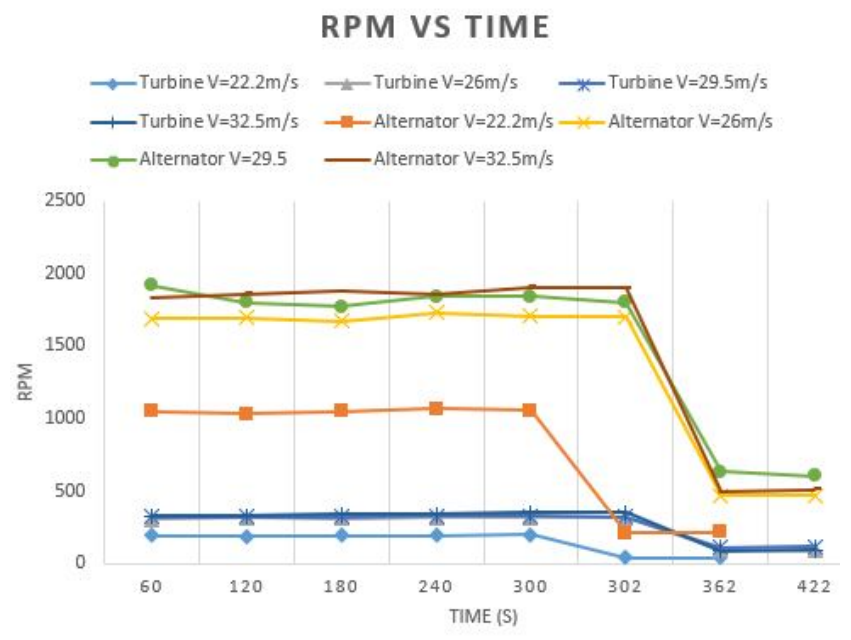

Figure 12: RPM of Turbine and Alternator in 5 minutes test run of AWG (Belt: 4PK Ribbed Belt; $\mathrm{t}=0.9 \mathrm{~mm}$; with BG)

From the experiments, the optimum speed rated that compromised wind speed, $v$ or when vehicle speed varies from $80 \mathrm{~km} / \mathrm{h}$ to $118 \mathrm{~km} / \mathrm{h}$ are $600 \mathrm{RPM}$ for $\mathrm{V}$ belt and 400 RPM for V Ribbed belt, but not reach the minimum speed of alternator for charging a battery. Both results highlights that the selection of generator must consider the application, wind speed and rated speed of the generator by the manufacturer.

Otherwise the car alternator does not design for open environments such as on the roof of a car and it may damage by rain water. The proper heat dissipation for cooling purposes make it only suitable inside the cabin or bonnet with good ventilation. Table 8 summarizes the comparative studies for alternator type, maximum speed rate, rated current, minimum speed for charging, gear ratio and their application.

Table 8: Comparative study of rated speeds of generator in the experimental

\begin{tabular}{|c|c|c|c|c|c|}
\hline Researcher & $\begin{array}{c}\text { Alternator } \\
\text { type }\end{array}$ & $\begin{array}{c}\text { Rated } \\
\text { Current } \\
\text { (A) }\end{array}$ & $\begin{array}{c}\mathbf{N}_{\min } \\
(\mathbf{R P M})\end{array}$ & $\mathbf{G}$ & $\begin{array}{c}\text { Applied } \\
\text { for }\end{array}$ \\
\hline$[9]$ & $\begin{array}{c}\text { Car } \\
\text { Alternator } \\
\text { Proton } \\
\text { Preve }\end{array}$ & 90 & 2000 & 2 & $\begin{array}{c}\text { Passenger } \\
\text { car }\end{array}$ \\
\hline$[10]$ & $\begin{array}{c}\text { Car } \\
\text { Alternator } \\
\text { (Bosch } \\
\text { ALT-2118) }\end{array}$ & 110 & 1200 & 8 & $\begin{array}{c}\text { Micro Gas } \\
\text { Turbine }\end{array}$ \\
\hline$[11]$ & $\begin{array}{c}\text { Car } \\
\text { alternator }\end{array}$ & 45 & 1070 & 8.3 & $\begin{array}{c}\text { Wind } \\
\text { Turbine }\end{array}$ \\
\hline$[12]$ & $\begin{array}{c}\text { Car } \\
\text { Alternator } \\
\text { Perodua } \\
\text { Myvi }\end{array}$ & 65 & 1400 & 2 & $\begin{array}{c}\text { Passenger } \\
\text { car }\end{array}$ \\
\hline
\end{tabular}

$* \mathrm{G}=$ Gear ratio, $N_{\min }=$ Minimum $\mathrm{RPM}$ for charging the battery . 


\section{CONCLUSION}

In the experiment, four Blade Thickness (BT) of Savonius wind turbine with Unidirectional RH was developed and the performance was compared to determine the higher RPM of the reconstructed alternator and its charging capability. In the apparatus set up, the rotor was equipped with different BT, $\mathrm{t}=0.9 \mathrm{~mm}, 1.2 \mathrm{~mm}, 1.5 \mathrm{~mm}$ and $2.0 \mathrm{~mm}$ for test stand on AWG with RH and V Ribbed belting system, G=6.4. The experiment was performed in a wind tunnel with wind speed, $\mathrm{v}=22.22 \mathrm{~m} / \mathrm{s}$. Besides this, test run AWG on passenger car to observe the output voltage and vehicle speed using BT with the higher RPM only. Then, the BT with the higher RPM has been continued for wind speed $\mathrm{v}=22.22 \mathrm{~m} / \mathrm{s}, 26 \mathrm{~m} / \mathrm{s}, 29 \mathrm{~m} / \mathrm{s}$, and $32.8 \mathrm{~m} / \mathrm{s}$ to determine charging capability test. The main performance parameters are RPM, output voltage and current generated were monitored to compare the overall performance of the rotors that using two belting system; V belt and V Ribbed belt.

During the test stand on AWG, the higher RPM ( $\mathrm{v}=22.22$ $\mathrm{m} / \mathrm{s}$ ) was found for rotor equipped with $\mathrm{BT}, \mathrm{t}=0.9 \mathrm{~mm}$ with 920 RPM with $103 \mathrm{mV}$ where the relationship between RPM with output voltage were performed. From test run AWG on the passenger car using BT, $\mathrm{t}=0.9 \mathrm{~mm}$ the maximum output voltage for $148.5 \mathrm{mV}$ where during the test no Blade Guider (BG) was used, thus the car speed was slowed down as there has the collision between the blades and $\mathrm{RH}$ occurred when vehicle speed reach at $30.5 \mathrm{~m} / \mathrm{s}(109.8 \mathrm{~km} / \mathrm{h})$ after longer running time causing the blade more wider as monitored during test stand also.

Then, the AWG rotor was equipped with BG for further test stand in identifying the charging capability of AWG with RH and BT, $\mathrm{t}=0.9 \mathrm{~mm}$. From this experiment, the alternator with $\mathrm{V}$ belt has rotated in the range of $487 \mathrm{RPM}$ to $758.3 \mathrm{RPM}$ for wind speed in the range, $v=22.22 \mathrm{~m} / \mathrm{s}$ to $32.8 \mathrm{~m} / \mathrm{s}(80 \mathrm{~km} / \mathrm{h}$ to $118 \mathrm{~km} / \mathrm{h}$ ) when the switch is on. While for V Ribbed belt has the range of alternator rotation; 218.6 to 634 RPM for wind speed in the range, $v=22.22 \mathrm{~m} / \mathrm{s}$ to $32.8 \mathrm{~m} / \mathrm{s}(80 \mathrm{~km} / \mathrm{h}$ to 118 $\mathrm{km} / \mathrm{h}$ ) when the switch is on. Thus, AWG with RH that using $\mathrm{V}$ Belt has the highest torque produced than V Ribbed belt where the losses due to the magnetic effect of the alternator rotor as the switch are on about $45.86 \%$ to $47.8 \%$ for turbine, while $47.5 \%$ to $48.7 \%$. While for V Ribbed belt, the losses are $65.35 \%$ to $79.23 \%$ for wheel turbine and $65.35 \%$ to $79.21 \%$ for alternator as the switch is on.

Therefore, AWG with a reconstructed alternator with $G=4.3$ using $\mathrm{V}$ belt has the optimum speed rate of alternator about 600 RPM, while for V Ribbed belt with $G=6.4$ has the speed rate of alternator about 400 RPM. The combination of Air wheel with the Reconstructed alternator as AWG did not reach the standard alternator speed rate about 1400 RPM during switch is on. Thus, installation of the standard PMDC generator that has a lower speed rate can be used for a good combination for AWG with uni-directional $\mathrm{RH}$ that has proven data in generating the electricity. Otherwise, the conversion of standard car alternator as the standard PMDC with waterproof may be equipped to the existing AWG with modification on the rotor as permanent magnet structure.

In future studies, it may also be applicable for different designs of Savonius turbine using material such as fibreglass, carbon fibre and suitable natural fibre. Other than that, the effect of end plate on the rotor blade or rotor bucket with additional of the wind nozzle at the entrance that may be equipped on RH to increase the alternator RPM and its charging capability.

\section{ACKNOWLEDGMENTS}

The authors thanks to Ir. Dr. Noorazizi bin Mohd Samsuddin for encouragement. The grateful to Universiti Teknologi Malaysia and Kelana Jaya Community College for providing the facility for this study.

\section{REFERENCES}

1. M. Waqas and N. Ahmad, Effect of hot climate condition on the performance of savonius type vertical axis wind turbine, in $3 r d$ Int. Conf. Energy Conserv. Effic. ICECE, IEEE, Oct. 2019, pp. 1-5 doi: 10.1109/ECE.2019.8920987.

2. A. K. Mandal, K. B. Rana, and B. Tripathi. Experimental study on performance improvement of a Savonius turbine by equipping with a cylindrical cowling, in Energy Sources, Part A: Recovery, Utilization and Environmetal Effect, 2020, pp. 1-19, doi: 10.1080/15567036.2020.1772907.

3. A. L. Manganhar, A. H. Rajpar, M. R. Luhur, S. R. Samo, and M. Manganhar, Performance analysis of a savonius vertical axis wind turbine integrated with wind accelerating and guiding rotor house, Renew. Energy, vol. 136, pp. 512-520, Jan. 2019, doi: 10.1016/j.renene.2018.12.124.

4. N. P. Putri, T. Yuwono, J. Rustam, P. Purwanto, and G. Bangga, Experimental studies on the effect of obstacle upstream of a Savonius wind turbine, SN Appl. Sci. 1, vol. 10, no. 1216, Sept. 2019, doi: 10.1007/s42452-019-1253-2.

5. M. Mohammadi, R. Mohammadi, A. Ramadan, and M. H. Mohamed, Numerical investigation of performance refinement of a drag wind rotor using flow augmentation and momentum exchange optimization, Energy, vol. 158, pp. 592-606, June 2018, doi: 10.1016/j.energy.2018.06.072.

6. SAE. Road vehicles-alternators with regulators-test methods and general requirements, $S A E J 56$, June 1999, pp. 1-7.

7. S. Tickoo and C. Tech. Wind turbine for automobiles, Environmental Sciences. American Society for Engineering Education, 2011.

8. D. M. Kurniawati, D. D. D. P. Tjahjana, and B. Santoso. 
A Q Mohd Radzi et al., International Journal of Emerging Trends in Engineering Research, 8(1.1), 2020, 45 - 53

Experimental investigation on performance of crossflow wind turbine as effect of blades number, in Proc. AIP Conf. 1931, 2018, pp. 1-7, doi: 10.1063/1.5024104.

9. R. K. Mazlan, R. M. Dan, M. Z. Zakaria, and A. H. A. Hamid. Experimental study on the effect of alternator speed to the car charging system, in Proc. MATEC Web of Conf., 2016, vol. 90, no. 1076, pp. 1-10, doi: 10.1051/matecconf/20179001076.

10. K. Sim, B. Koo, C. H. Kim, and T. H. Kim, Development and performance measurement of micro-power pack using micro-gas turbine driven automotive alternators, Appl. Energy, vol. 102, pp. 309-319, Jan. 2013, doi: 10.1016/j.apenergy.2012.07.014.

11. S. O. Ani, H. Polinder, and J. A. Ferreira, Small wind power generation using automotive alternator, Renew. Energy, vol. 66, pp. 185-195, Jan. 2014, doi: 10.1016/j.renene.2013.12.006.

12. A. Q. Mohd Radzi, Design optimization of air wheel generator in energy harvesting on passenger car, Ms project, Razak Faculty of Technology and Informatics, Universiti Teknologi Malaysia, Kuala Lumpur, 2020.

13. A. Q. Mohd Radzi, M. S. Noorazizi, R. Mohammad, and S. A. Aziz. Design optimization of Savonius wind turbine using particle swarm optimization, in 10th Int. Conf. Mech. Manuf. Eng. ICME 2019, Melaka, 2019,

no.

46-7413.https://icme.uthm.edu.my/2019/index.php/pub lications. "to be published"

14. F. Wenehenubun, A. Saputra, and H. Sutanto, An experimental study on the performance of Savonius wind turbines related with the number of blades, Energy Procedia, vol. 68, pp. 297-304, March. 2015, doi: 10.1016/j.egypro.2015.03.259.

15. B. Balta, F. O. Sonmez, and A. Cengiz, Speed losses in v-ribbed belt drives, Mech. Mach. Theory, vol. 86, pp.1-14, Jan. 2015, doi:10.1016/j.mechmachtheory.201 4.11.016. 